\title{
The Potential Use of Electromagnetic Radiation to Combat Severe Acute Respiratory Syndrome Coronavirus 2 (SARS-CoV-2) Particles: A Numerical Analysis
}

\author{
Haider Raad ${ }^{1}$ and Colin Terry ${ }^{1}$ \\ ${ }^{1}$ Xavier University
}

September 25, 2021

\begin{abstract}
The novel coronavirus disease 2019 (COVID-19) has shown the danger that can be caused by small, airborne and contagious virus particles such as severe acute respiratory syndrome coronavirus 2 (SARS-CoV-2). To prevent the mass spreading of such viruses, the use of electromagnetic waves could be used to combat the spreading of the virus. Particularly, the waves could force any virus particles to oscillate in resonance with the frequency of the wave and destroy themselves before the virus would enter the respiratory system. This paper describes the use of numerical simulations to analyze the effects of exposing a SARS-CoV-2 particle to electromagnetic waves at a range of frequencies and to determine which frequencies have the potential of causing resonance within the virus which would yield to the maximum energy absorption. Such technique could be utilized in preventive/protective devices and disinfection equipment.
\end{abstract}

\section{Hosted file}

Main_Text-Raad-Engineering Reports.pdf available at https://authorea.com/users/436540/ articles/538783-the-potential-use-of-electromagnetic-radiation-to-combat-severe-acuterespiratory-syndrome-coronavirus-2-sars-cov-2-particles-a-numerical-analysis

\section{Hosted file}

Main_Text-Raad-Engineering Reports.docx available at https://authorea.com/users/436540/ articles/538783-the-potential-use-of-electromagnetic-radiation-to-combat-severe-acuterespiratory-syndrome-coronavirus-2-sars-cov-2-particles-a-numerical-analysis 



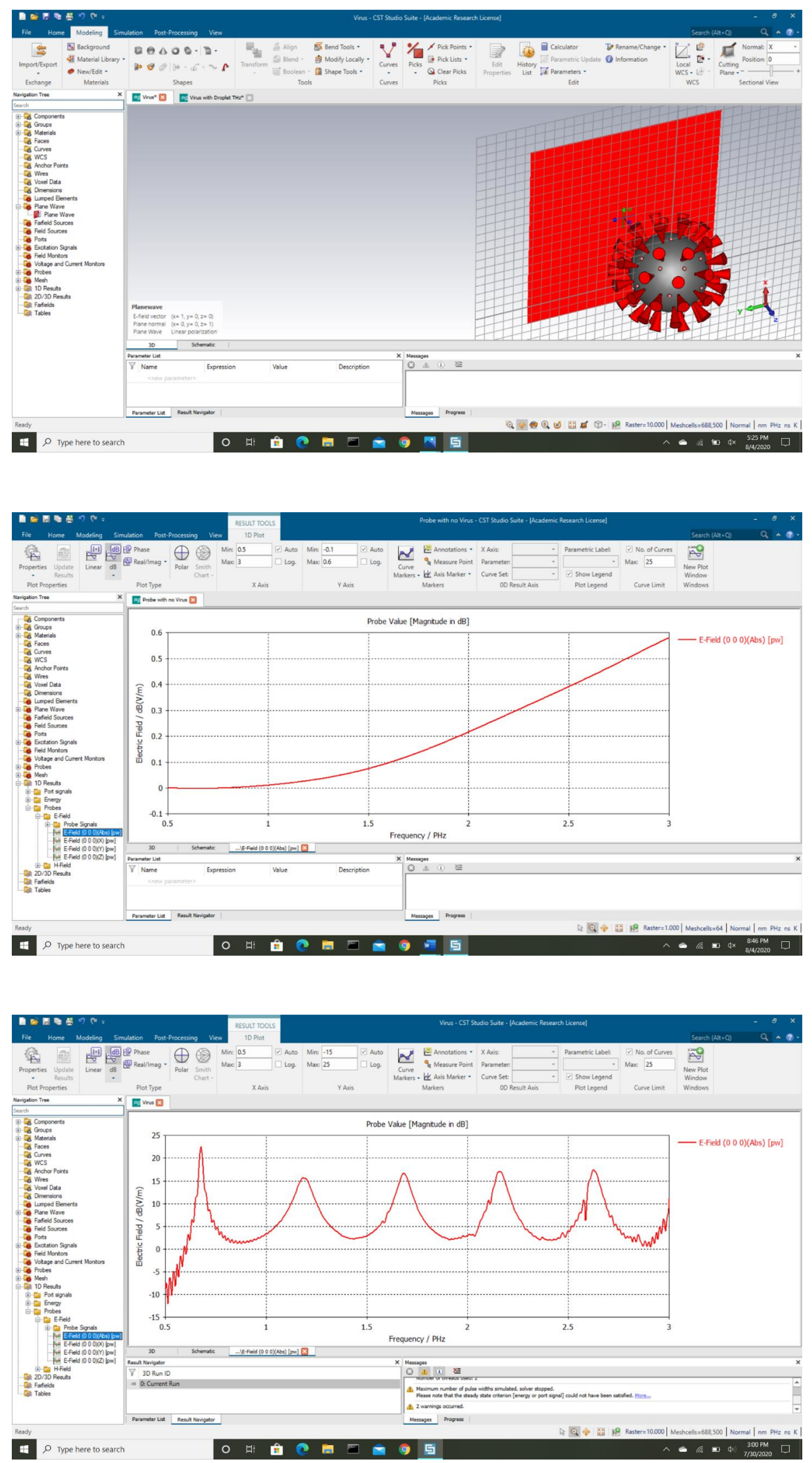

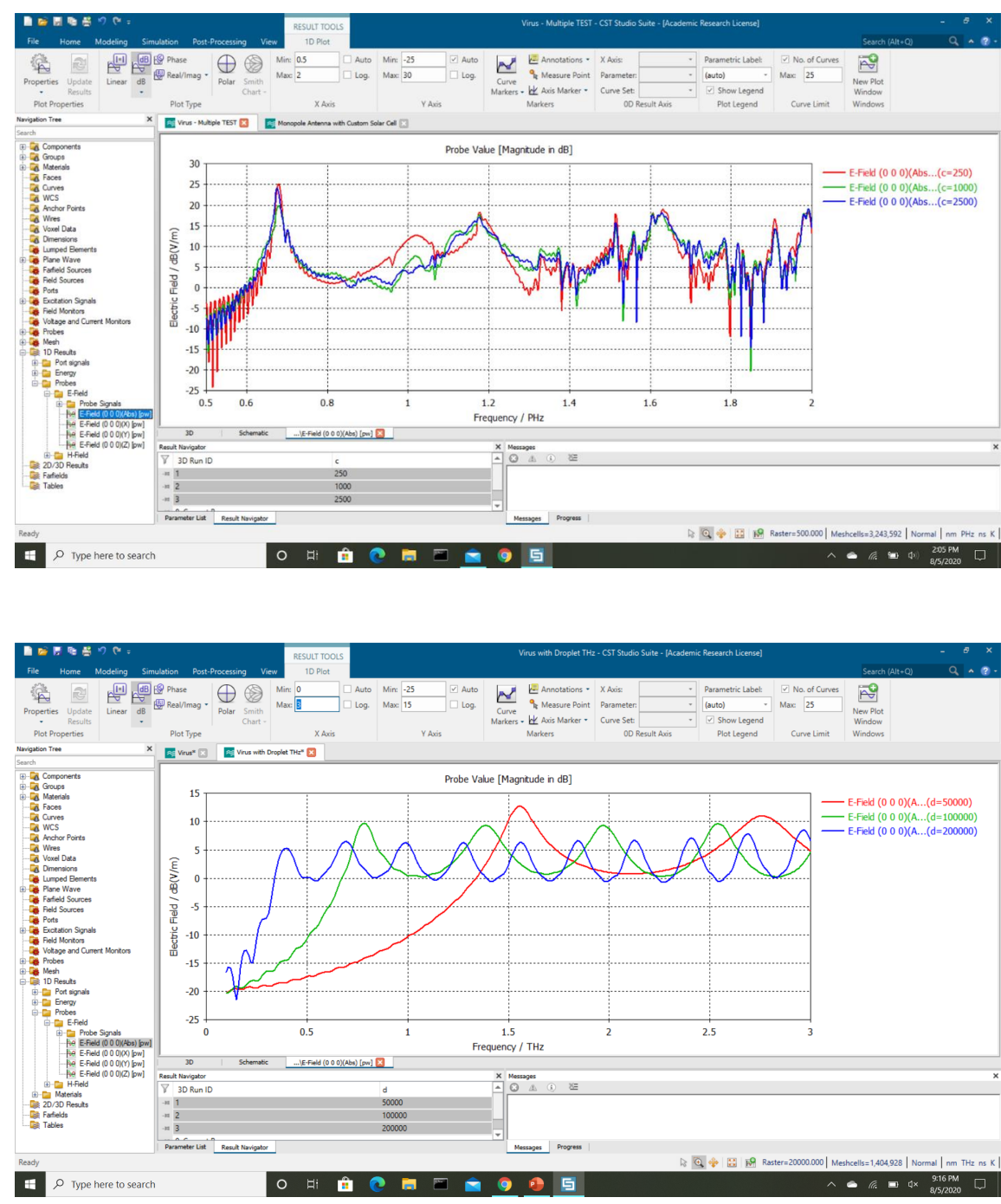